УДК

DOI: $10.18384 / 2310-712 X-2019-3-113-140$

\title{
THE IMPACT OF RUSSIAN CULTURE ON THE POLITICAL ORIENTATION OF WESTERN EXPATRIATES IN RUSSIA
}

\author{
J. G. Harrison \\ Moscow Region State University \\ 24 ulitsa Very Voloshinoi, Mytishchi 141014, Moscow Region, Russian Federation
}

Abstract. This paper strives to show the importance of links between culture and politics, which some analysts say has been sadly neglected in contemporary political science. The theoretical base for this research includes reference to the 'degree of acceptance' of a call to securitise an issue or event. Such a 'degree of acceptance' of a securitisation issue or event, it is argued, may vary because of differing cultural norms in different countries. Transculturism, which advocates, in broad terms, seeing the 'we' in the 'other,' is also discussed in terms of identifying a theory which reifies culture as being of fundamental importance to global security. The measurement of alterations in the political views, over time, of western expatriates working and living in Russia is used as a case study. The tense East-West political environment at the time of writing this paper provides a sufficiently contrasting political climate within which any alterations of political orientation of western expatriates who took part in the research could be observed. Research showed that the political orientation of expatriates did not change in a 'black and white' way, however expatriates seem to develop and assimilate a second political identity, which gives them a meaningful (for them) alternative point of view on Russia and global security in general.

Keywords: Russian culture, the political orientation, degree of acceptance, Transculturism, Buzan, seeing the 'we' in the 'other, western expatriates.

\section{ВЛИЯНИЕ РУССКОЙ КУЛЬТУРЫ НА ПОЛИТИЧЕСКУЮ ОРИЕНТАЦИЮ ЭМИГРАНТОВ ИЗ ЗАПАДНЫХ СТРАН В РОССИИ}

\author{
Харрисон Дж. Дж. \\ Московский государственный областной университет \\ 141014, Московская обл., г. Мытищи, ул. Веры Волошиной, д. 24, \\ Российская Федерация
}

Аннотация. В статье подчёркивается значимость связи между культурой и политикой, которую в современной политической науке некоторые аналитики, к сожалению, не учитывают. Теоретическая база исследования включает «степень принятия» призыва к обоснованию безопасности проблемы или события. Подобная «степень принятия» безопасности проблемы или события может варьироваться в зависимости от культурных норм, принятых в разных странах. В статье транскультуризм рассматривается как видение «нас» в «другом» в рамках теории, утверждающей, что культура имеет первостепенное значение для мировой безопасности. Измерение изменений политических взглядов эмигрантов из

(C) СС ВY Харрисон Дж. Дж., 2019. 
западных стран, работающих и живущих в России, используется в качестве материала исследования. Можно наблюдать изменения политической ориентации эмигрантов из западных стран, принявших участие в опросах, происходящие в период напряжённых политических отношений между Востоком и Западом, пришедшихся на время написания этой статьи. Как показывают результаты исследования, политическая ориентация эмигрантов не изменилась кардинально, сменив «чёрное на белое», однако экспатрианты, по-видимому, развивают и принимают вторую политическую идентичность, что даёт им значимую (для них) альтернативную точку зрения на безопасность России и мира в целом.

Ключевые слова: русская культура, политическая ориентация, степень принятия, транскультуризм, видеть «нас» в «других», западные экспатрианты.

\section{Introduction}

This paper is concerned with the role that culture plays in global security. More specifically, it explores the relationship between cultural identity and political identity [41, p. 10].

Discussing the role of culture on politics and global security is not something new. Thucydides, for example, discussed the effect of culture (as 'modes of life') on the political thinking of leaders in the ancient states of Greece [35]. Rushing forward to the $20^{\text {th }}$ century, Mamdani linked the end of the Cold War and 9/11 to the rise of 'Culture Talk', which 'assumes that every culture has a tangible essence that defines it, and it (Culture Talk) then explains politics as a consequence of that essence' [26]. Recent research has concentrated on the connection between individualism and democratisation, and suggests that countries where collectivism is more prevalent historically and culturally are less likely to adopt a western-style democratic system than countries whose culture is more amenable to that $[8 ; 19]$. Hofsted suggests a correlation between individualism and the average polity index [8].

Discussions about the importance of culture, however, have not always led to the application of security theories which include culture as being of major importance. If culture is taken into consid- eration, there is no guarantee that people who are members of one cultural group will view people who belong to another culture in an unbiased way [16, p. 93]. Understanding a foreign culture may involve being immersed in the culture involved. Immersion in another country's culture, as this research will hopefully show, involves a temporal factor. The understanding of foreign cultures, however may simply not be recognised as being very important. This is despite the availability of evidence which suggests that culture forms our individual identities; identities which are reinforced by comparing ourselves with others at a young age $[2$, p. $30 ; 3$, p. $2 ; 15 ; 41$, p. 5]. It appears difficult to understand how other people from another culture view the world, even more difficult to understand others' motivations without applying judgements based on our own cultural values. Most significantly, understanding how other people view the world is in itself perhaps not a key part of realist global security theory, as shall be discussed in the literature review (chapter 2).

This paper sets out as its goal to highlight the importance of culture in global security. The method chosen is to select citizens living in a foreign country which has a different culture, by evaluating if the foreign culture involved effects their 
political orientation. If such a tendency is shown, then data gathered would give weight to the argument that culture affects politics, and that the role of culture is in fact underestimated in global security thinking today. The way that this was carried out in this research was to look at western expatriates living in Russia, and to find out if their adopted cultural environment has affected their political orientation.

The method applied to evaluate if Russian culture impacts the political views of expatriates was to ask the same open-ended questions to expatriates who had lived in Russia for differing lengths of time, and then come to a conclusion by comparing the results. The key interview question was determined to be: 'Does long term residence and cultural immersion in Russia impact upon the political views of expatriates living in the Russian Federation?' Interview topics focussed on any shift in political views in regard to both Russia and their home countries. By way of understanding the role of culture in a possible alteration of political orientation, questions were also asked about culture in general. So as to establish credibility of the research, it was important to establish that respondents are not becoming cut off in any way from their own cultures, thus questions concerning access to their own countries were added. A more detailed description of the research design is to be found in the methodology (chapter 3).

Analysis of data (chapter 4) was based on two main goals. Firstly, to answer the main research question and secondly to delve into causational factors behind the data received from the main question. A conclusion (chapter 5) offers links between the findings of this research and global security.

\section{Literature Review}

As already discussed, this paper is concerned with the effect of culture on global security. The first section of this review looks at contemporary global security literature which considers culture. The second section contains references to literature pertaining to the Russia-West dialogue, as this is of direct relevance on both theoretical and practical levels to this paper. The third section of this literature review shall contain a brief review of existing surveys of expatriates carried out in Russia. Reviewing literature in these sections was necessary to provide the necessary context and background information in order to carry out research.

\subsection{Global Security Literature}

In general terms, global security since the end of the Cold War reveals a progression away from realist 'black box' thinking. Realist thinking, in general terms, enabled governments to convince their citizens that the main threat facing them was the use of military force, and survival of the State was essential at any cost, towards considering human beings' security as being at least as important as the security of the State (Glaser in [16, p. 15] and $[31 ; 36])$. Such theoretical literature found their way into security policy. An example of this would be how the major tenants of 'Human Security' were adopted by the UN. See the UN charter chapter V, article 23 (United Nations), and 1994 United nations UNDP report [14].

Within this underlying shift from realist to non-state-centred security, the importance of culture, although this word was not used widely in global security literature until as late as the 1990s, began to be recognised as an important factor with research undertaken by the 'Copenhagen School', and continued by other scholars 
within the schools of 'Critical Security Studies' [16; 23; 38]. The Copenhagen School's 'sectoral approach' was at the time a radical innovation, as it included both military and non-military sectors to be worthy of being securitised. The 'sectoral approach' classified global security into military, political, economic, environmental and societal security [12, p. 195-197]. The 'societal' was referred to in terms of patterns of language, culture, religions, national identities and customs of States. However, a critical analysis of the 'societal' in Buzan's interpretation reveals that the main security concern remains military threats, with the 'State' remaining the main object under 'threat,' and the 'societal' remaining without a clear definition (Paul Roe in [16, p. 177-189]).

Wæver and Calton's development of 'societal security', by developing a duality of State security and 'societal security' can be seen as an ingenious attempt to circumnavigate this problem $[2$, p. $25 ; 12$; 41, p. 25]. By considering the 'societal', the Copenhagen School does point out the importance of culture, something that realism in global politics did not recognise to be particularly significant, except in the case when a government securitises culture as a way to force or threaten another country or group of people possessing a different cultural identity.

The Copenhagen School highlighted 'national identity' as being by far the most important component of the 'societal' sector. It forms: 'the most important form of large-scale social and political identity' [41, p. 22]. Wæver's consideration that culture and language are an integral part of such a 'national identity' is of direct relevance to this paper, as is his conviction that this is the main object to which people make reference to when they argue who 'we' are, and why 'we' belong together, along with a 'collective proper name, a myth of common ancestry, shared historical memories, an association with a special homeland, and a sense of solidarity' [41, p. 30]. Culture was seen to Wæver as being a major part of 'national identity' [41]. However, Waever is not stressing that culture can impact politics, rather suggesting that 'there may be identities within states which are not necessarily coterminous with the state that may be securitised' [2, p. 13].

It is necessary to point out, that discussions about cultural and political identity within explorations of the 'societal' as proposed by the Copenhagen School seem to suggest that cultural identity is formed in part or in whole by political identity [41, p. 10]. The review of such literature was useful for the purpose of exploring the theme that not only cultural identity is informed by political identity (as Wæver and Carlton suggest), but that the reverse may also be possible, as is explored in this paper.

Another development within the Copenhagen School, was the importance played on the speech act with securitisation theory. The implications of the 'speech act' serve as the inspiration for the writing of this paper. Buzan argued that 'the securitising process requires some $d e$ gree of acceptance between the perpetrator of the securitising speech and the relevant audience that is appealed to otherwise, a securitising move remains incomplete' [12]. Certain felicity conditions, such as the authority of the speaker also have to be met [4]. This paper argues that there is more of a direct link between culture and (in)security than has hitherto been recognised; as Al-Rodhan points out: 'culture has not been given as much attention as 
perhaps it should have in security thinking' [2, p. 13]. The 'degree of acceptance,' in the opinion of the author, is directly linked to culture. It is suggested that if we accept that it is possible to securitise an issue through a speech act, then we have to accept the influence of culture. Culture makes it possible to accept that an issue is important enough to be securitised. Different cultures securitise different issues according to the semiotic codes and hierarchies that particular cultures place on different signs and aspects of indigenous culture.

The authors of societal security stand accused of supporting an essentialist view of culture [28]. McSweeney is concerned that the concept of societal security risks legitimising the notions of 'us' and 'them.' This paper does not claim to support or refute McSweeney's point of view, however Buzan and Waever's point that 'once mobilised, identities have to be reckoned with as something that people perceive they belong to, and act upon as objective, given' is hard to refute in the opinion of the author [12, p. 246].

Buzan and Waever consider ethnicity to be an important part of national identity. However they also state that the relationship between ethnicity and national identity is a variable factor [41, p. 36]. Thus countries with strong legal infrastructures may be more able to support a 'multi-ethnic' identity than those which are still forming such a framework [33]. Stating that such a relationship may vary is not the same thing as creating a theory which accommodates variations, as the relationship between the two in western countries may be different from that in many eastern countries. This may affect the relationship between the Copenhagen School's 'societal' sector and other sectors.
A fundamental criticism that can be levelled at many schools of western security studies, including the Copenhagen's School 'Societal Security' is that they presume that a broadly western democratic political structure with a mature legal system that facilitates such astructure is the point from which analysis starts. There is doubt whether their models can be applied outside Europe or to non-liberal democracies [40; 43].

It is important to emphasise that the object of study in this paper is to establish if culture affects the political orientation of expatriates in Russia, and to shed some light on the how, not to dwell on the debate whether culture exists at all. The term 'culture' for the sake of this paper could be replaced with the term 'mind set.' The approach taken by Pierre Bourdieu who is interested in connections between the 'cultural field' and the socio-political context, and who appears to accept the existence of internalized structures or sets of structures that determine how an individual acts within the world, and reacts to the world, suggests a middle ground approach suitable for application in this paper $[7 ; 10]$. Bourdieu's sets of structures in this context resonate with Wæver's consciousness of 'we', but contrast with a 'soft constructivist' approach.

\subsection{Russia-West Dialogues}

As this research involves Russia, it is useful to frame this study within literature that offers insights into Russia-West dialogues. Two main schools of thought, which in many aspects can be seen to overlap, are relevant to this paper. Firstly, literature describing the unidirectional force of globalisation, and secondly, literature which discusses the Russia- West dialogue.

Literature describing the nature of globalisation, which can include not only 
flows of capital but also ideas, needs to be considered for this paper, as many expatriates in Russia are in fact instigators of global capitalism [5]. Literature which suggests that globalisation includes a homogenising process of westernisation [6] can be contrasted by views put forward by Appadurai and others, that globalisation includes an indigenisation process $[3 ; 13]$.

One of the unavoidable aspects of this research is to ascertain expatriates' views of current West-East dialogues, in particular the image of Russia as portrayed in western media. Another is to ascertain whether exposure to Russian culture alters their perceptions of what may be stereotypes. In the context of stereotypes, it was useful for the researcher to read about views such as that offered by Lievan, that anti-Russia sentiment began well before the present day Russia, and even before the Soviet Union. Lievan proposes that 'Russophobia', for example, grew out of British attitudes towards the expanding Russian empire in the 19th century [25]. Brown claims that stereotypical views of Russia derive from Cold War period 'Russian Studies' which were 'orientalist' by nature [9]. Other examples of orientalist thinking of Russia include that offered by Spengler that the Soviet Union was a continuation of Tsarist imperialism [34]. Godard and Gibbons offered an explanation for the popularity of communism in Russia being due to 'the primitive and non-European qualities of that country.

\subsection{Expatriates as Migrants}

Other literature of relevance to this paper includes discussions of the nature of migrant cultures, in particular, whether western expatriates in Russia can be considered migrants or not. In this context, the work of von Koppenfels, who studied Americans working in Europe was found to be useful [22]. Von Koppenfels regards such workers as transnational workers rather than migrants, one reason being that such workers are not generally forced in any way to leave their home countries to survive economically, in the same sense of the term as migrants from Central Asia, many of whom have no choice but to travel to Russia to work and send money home to their families $[1 ; 24]$.

Western expatriates being researched in this paper cannot be seen to be numerous enough or permanent enough to constitute a diaspora, according to Brubaker and Cooper's criteria [10]. There is no immediately available source whereby the numbers of expatriates can be accurately assessed. The British embassy in Moscow, for example, no longer requests that expatriates register with the British embassy, and this is the case with most western embassies. The Russian government keeps figures of foreigners residing inside the Russian Federation, but there is no separation into categories, such as tourists and expatriates. Approximate estimates based on ambassadors' records to which the author was able to enquire about, reveal that from a peak of 500,000 expatriates resident in Russia in 2008, there are currently approximately 100,000 [42].

The question of whether expatriates present a threat to their host countries, or perhaps to themselves by living in a particular country is discussed by Vertovec, however for reasons given above, it may not be possible to show a clear parallel between the migrants that Vertovec talks about and western expatriates in Russia [39]. Expatriates may, however, be vulnerable to attacks of various kinds, which is a topic Vertovec brings up, albeit it on the level of political propaganda, and this is a subject that is relevant and researched in this paper. 
Von Koppenfel's work was also useful by way of supplying background information about transnational workers in other countries [22]. The Americans working in Europe that she studied retain political allegiance to the U.S. through maintaining socio-economic ties with home. They also retain, according to the author, American cultural traditions and pass them on to their children. American expatriates in Europe (as many western expatriates in Russia) appear to be in a privileged position, and at the same time, there are 'middling migrants' whose financial position may not be strong. The comparison between the privileged and 'middling migrants' in terms of transnationalism and retention of their original political orientation is of interest to von Koppenfel, and it opens up another aspect of research for empirical research within the parameters of this paper. For example, von Koppenfel's work suggests questions as to what kind of links western expatriates maintain on a cultural level with their home countries. Questions concerning this subject were included in the topic guide, although the current research is not so much concerned with the sociological make up of expatriates, as to whether or not expatriates' political orientation is altered by exposure to Russian culture. The expatriate's social position, however, may have an effect on political orientation as this might determine, for example, the expatriate's ability to travel home regularly.

\subsection{Literature Concerning Expatriates}

The main body of literature dedicated to the expatriate field concerns cross-cultural communication, and is targeted at business people who need to familiarize themselves with local business culture in preparation for their assignments, and to help them use their skills more adequately within a foreign environment. Such literature $[20 ; 32]$ is of limited use for this paper as it points out completed cultural differences but does not attempt to analyse the effect of such differences on individuals, if he or she is exposed to a foreign culture for a number of years, a process that is empirically researched in this paper.

A survey of western libraries' databases reveals that academic literature concerning expatriates in Russia is almost non-existent. Two surveys have been carried out relatively recently. The first was quantitative, and concerns a joint project by the St. Andrews Anglican Church and Centre in Moscow and the magazine Moscow Expat Life [29]. This was the second survey such survey carried out into the Moscow (western) expatriate community, and the objective was to find out the make-up of the expatriate community. Interesting data was established such as the percentage of expatriates who have lived in Russia for over 10 years, and their knowledge of Russian. The survey established relationship status (54\% married, $14 \%$ in a relationship and $32 \%$ single). Employment (83\% of respondents said they were employed, $3 \%$ retired, $4 \%$ unemployed, and $10 \%$ classified themselves as dependents). Age groups were identified, and expatriates' reading habits were recorded (but only within the confines of the Moscow English language press). Research established what social clubs foreigners belong to if any, and other aspects of their lives such as religious beliefs and involvement in charity work. This survey can be seen as an excellent source of statistics, but lacks causational analysis, and this served as a clear pointer for the author to choose a qualitative design strategy for this paper.

A more detailed, academic, and qualitative survey was carried out by the 'Kha- 
movniki Sociological Research Fund' in the summer of 2014 just before the Ukrainian crisis started. The survey provides useful background information on the number of expatriates in Russia at that time, their occupations, and the kind of people who come to Russia to work [42]. The survey concentrates on what expatriates think of Russians and Russia but is not concerned with the depth of which expatriates are affected, or not affected by Russian culture.

The literature review as above supplied a basis for understanding existing theoretical works relevant for this paper, as well as providing knowledge of research already carried out into this theme. It was discovered that existing theoretical work that concerns the importance of culture in global security is not as abundant as the author presumed. It was also discovered that there is a general lack of academic literature regarding possible changes of expatriates' political orientation, and hardly any literature concerning expatriates in Russia.

\section{Methodology}

This chapter will discuss the methodology used in this paper. The research strategy and design shall be presented, with references to issues connected with sample frame and design within a specific environment.

\subsection{Research Strategy}

The main object under analysis is expatriates' understanding of the relationship between culture and politics. In this context, the debate about differences between how the 'hard' and 'soft' constructivist schools view identity as discussed in the literature review is important because this has implications on the ontological position adopted. At the stage of prepar- ing the research strategy, the author was reluctant to come down firmly on either side of this debate, indeed, one of the goals of research was to in fact establish whether a 'hard' or soft' constructivist view of identity and culture is more correct in the case of Russia.

Adopting an objectivist position would have meant that culture acts as a constraining force because we internalise beliefs and values [11, p. 32]. On the other hand, expatriates' own values and belief systems may be seen to change, which would indicate that their perception and interpretation of culture can change. A compromise position was considered, whereby it is necessary to appreciate that culture has a reality of its own, which acts as a point of reference, but at the same time is always being formed. This last view was the standpoint adopted for the purpose of conducting research for this paper (Becker,quoted in [11, p. 34]).

Of importance when considering the research strategy and design was recognition that research would not be testing an established theory or hypothesis from the outset, thus the research needed to be inductive; an approach that includes the possibility that human behaviour is not determined by positivistic law-like regularities $[11$, p. $33 ; 30$, p. 24]. Thus the ontological position for the current research is situated closer towards idealism than realism.

Max Weber described sociology as a: 'science which attempts the interpretive understanding of social action in order to arrive at a causal explanation of its course and effects (MaxWeber, 1864-1920, quoted in [11, p. 29]).' Weber appears to be saying that in order to reach an interpretive understanding of social understanding, a general theory must be adopted, as 
interpreting something would seem to entail a set of truths in comparison to which understandings of social actions can be evaluated. The goals of this paper, however, demand that the researcher approaches the whole issue of culture and identity without preconceived conceptions as much as is possible, and rejects a 'scientific method' that accepts that all knowledge derives from our senses [30, p. 9]. The main idea is to understand rather than explain, although awareness of causational issues will hopefully deepen the impact of results to the key research question. Bearing in mind all of these points, the researcher adopted an epistemological position which rejects positivism in favour of an interpretivist approach.

\subsection{Research Design}

The data collection segment of this paper is inductive and broadly constructivist; necessitating a qualitative approach for the research. The key research question is: does long term residence and cultural immersion in Russia impact upon the political views of expatriates living in the Russian Federation? Topic guides were based around the following themes: Longevity of stay in Russia, contact with Russians, Russian language skills, involvement with Russian culture, political orientation etc., (see appendix 1, for full list of topic guides) and were formulated in a deliberately generalised way to enable a wide scope of responses.

Sampling was purposive, that is, the researcher was not seeking to sample research participants on a random basis [11, p. 418]. Semi-structured interviews were used for data collection, as it was foreseen that such an approach would allow for the gathering of information that the interviewer may not be aware of. At the same time, the research had a particular goal in mind; that is the establishment of a causational link between culture and politics, and the topic guide reflected this goal.

Ideally a longitudinal design could be employed to measure changes in the political orientation of the same expatriate respondents over time. As strict time constraints were fixed on this paper, it was not possible to employ this method. A crosssectional approach, which although is often associated with quantitative analysis $[11$, p. 62], was seen as suitable because this would allow a number of respondents to participate at the same period of time, and at the same time can be considered a qualitative method because semi-structured interview techniques can be used. Research carried out by Beardsworth and Keil (1992) (Quoted in [11, p. 63]), whereby the dietary beliefs and practices of 76 vegetarians in the East Midlands (UK) was studied using semi-structured interviews served as an interesting example of successful cross-sectional data collection. This example concentrates on what respondents 'experience.' The authors concentrated on a 'complex of interrelated beliefs, attitudes and practices;' themes which are fairly close to those discussed in this research. The two other research projects (mentioned in chapter 2) which have researched expatriates in Moscow over the past 25 years have also been organised on a cross-sectional basis for the above reasons $[29 ; 42]$. The time frame for research was a four-week period, from the 4 th of July until the end of the first week in August 2016.

For reasons of authenticity [11, p. 392393], two gatekeepers were recruited to recruit participants. One gatekeeper, who had arrived in Russia fairly recently (within three years) ran a social club in Moscow at the time of research which 
linked newly arrived expatriates together. This gatekeeper did not know how to contact expatriates who had lived in Moscow for long periods of time, so another gatekeeper, who works in education and who has been resident in Russia for 7 years was found to find participants who have been resident in the country for longer periods.

Attention was paid during the interview process to ensure that the author did not impose his own values and beliefs on the respondents in any way. If the respondent was expressing a pro-Russian idea, he or she was encouraged to do that, and if he or she was expressing the opposite, he or she was also encouraged to do that. In this way it was hoped that interesting data would be discovered, but also that the researcher would bracket himself from creating bias [11, p. 39-40]. The researcher was aware that conducting a completely unbiased interview is in fact impossible [11, p. 39; 37, p. 745], and therefore just before starting any of the interviews, made it completely clear to the respondent concerned that he did not have any desire to influence what the respondent might want to say in any way, and the success of the research being undertaken depended on the respondent speaking his or her mind.

The use of gatekeepers was found to be very useful, as without them it would have been all too easy to resist the temptation of finding a particular respondent who the researcher knew would respond in a certain way. The timing of the interviews turned out to be a serious problem in terms of participant recruitment as many expatriates were in fact on holiday during the research period, (most expatriates working in Russia seem to go away on holiday, 'en masse' in July and August, flowing the general Russian tradition of taking a sum- mer break during this period). Being on holiday, they were not readily available for interviews on Skype. Thanks to the gatekeepers, enough respondents were found, however, to able to conduct the research.

Another major concern as regarding the authenticity of the research was that respondents living in Moscow would not be representative of expatriates living throughout Russia. It was interesting to find out that only three of the twelve respondents interviewed lived in Moscow for most of their periods of residency in Russia. These three respondents were fully aware that their lifestyles and attitudes to Russia are influenced by the cosmopolitanism of Moscow. Three interviews were conducted with respondents who lived outside of the capital. One of them lives in Karelia, another in a city 720 kilometres from Moscow, and another in a conurbation in the Moscow District (Oblast'). The researcher travelled to these places to conduct interviews, as time was at a premium and it was not possible to wait until these respondents might travel to Moscow. The researcher was satisfied that any possible sampling bias which could have been created from carrying out most of the interviews in Moscow, which could influence research results in favour of a 'Moscow' rather than 'Russian' view of the world (as Moscow is seen by some to be more cosmopolitan than the rest of Russia) was not significant.

There was no defined sample size when research started, although recommendations were given. The approach adopted was that new participants would be invited until data gathered began to become repetitive [11, p. 421]. 10 expatriates were found by the gatekeepers, and another two were found through snowballing. The last two extra participants' views tended 
to corroborate data which had already been collected. This led the researcher to believe that the number of respondents interviewed was fit to purpose, although he was aware before research started of the danger of using snowballing as a recruitment technique (Rosenthal and Jackobson 1968 study quoted in [11, p. 54] and $[11$, p. 203]).

Because this research contains a temporal aspect, it was decided to interview respondents who had lived in Russia for different lengths of time. The lack of availability of expatriates over the summer period did not allow any further narrowing of the sample frame into nationalities, genders or numerically-defined lengths of residency in Russia. Originally, to simplify analysis, it was decided to interview only British people, as being a British citizen, the researcher is aware of background political circumstances in Britain, and it was felt that narrowing this down would make analysis for him easier. Such a selection proved to be impossible because there were not enough British expatriates willing to participate in July and August 2016. The data, however, showed such a selection would have been unnecessary and possibly restraining in terms of variety of responses in a qualitative research project. Furthermore, knowledge of participants' background political environment might have created bias in some way.

\subsection{Analysis}

It was found during research that new themes emerged from the data, as is common practice when undertaking qualitative analysis. For example, it was not understood before research started that none of the respondents had studied Russian before going to Russia, or studied Russian formally whilst in Russia. This led to development of a theme concern- ing the importance of language in culture. Understandings obtained from analysing the data was used to structure chapters 4 and 5 (Research Findings and Conclusion respectively).

It was envisaged that working with a relatively small number of participants (12) meant that creating links between themes and sub themes was possible without the use of CAQDAS software. Initially coding was carried out by highlighting printed transcripts of the interviews using coloured markers. During analysis, however, 43 nodes were discovered which was too many to be coded adequately using this method. Consequently, despite the small number of respondents, the researcher resorted to using NVivo software, and transcriptions of interviews were coded within NVivo. Sorting data according to length of time in Russia, for example, was found to be easier using this software, particularly as most of the transcripts tended to be long (over 3,000 words).

\section{Research Findings}

Data gathered revealed that the political views of western expatriates living in Russia are impacted by long term residence and immersion in Russian culture. However, such impact cannot be measured in terms of a 'black and white' switch over to a new way of viewing the world. Through analysis, this research hopefully shows that the longer an expatriate lives in Russia, the more he or she becomes aware of the Russian view of the world both in cultural and political terms. This gives the expatriate not only a different understanding of Russian politics, but also a deepening understanding that the culture and politics of his or her own country can no longer be taken as the only standard 
by which it is possible to judge and experience the world. Data gathered also revealed insights into the present state of Russian culture and identity.

The first section of the chapter presents and analyses respondents' answers to questions directly related to the key research question. The second section in this analysis deals with culture as a transformational force. The third section addresses other circumstantial factors, namely whether or not expatriates' views are being influenced by possible alienation from their own countries, and, expatriates' knowledge of Russian. Possible implications on global security shall be offered at the end of each section. Because the key question contains a temporal aspect, the amount of time that each respondent has been resident in Russia at the time of conducting the interview concerned, will be stated after the respondent's individual reference term.

\subsection{Main Research Results}

Research showed that respondents who have arrived in Russia within roughly two and a half years indicated that their views of Russian politics have been influenced by exposure to Russian culture. Their responses showed a tendency for political views already established before coming to Russia, which in all cases were non-sympathetic to Russia, to become more prominent. At the same time, their support and respect for the politics of their home countries was seen to have grown. A British teacher (1 year in Russia) said:

"...I think living in Russia has swung me more right wing."

"I'm sorry, but I don't understand what 'right wing' is."

"I mean I'm supporting Trump, if you say that is extreme then I guess it would be more on the extreme side. I would call my position, 'your country comes first'. And everything else comes after that."

Later in his interview he said:

"Has your attitude towards your own country's politics changed?"

"I admire British politics more. Because it is less corrupt than Russian politics. So I appreciate what David Cameron has done, even though he is stepping down now."

An Australian teacher, resident in Russia for 2 years said:

"I don't know a lot about foreign policy but what I would say is that there is definitely a lot of corruption among politicians in this country, and one example was the Panama papers when they came out, and how the trail led back to Putin, and obviously he denied everything..."

"So your understanding of Russian politics has changed over the years of living here?"

"No I don't think it's changed..."

"So you have come to respect your own country more than before?"

"There is so much more appreciation when I go to other countries about how, there is so much more acceptance from people about all different shapes and sizes and cultures, and races."

A French researcher, resident in Russia for 5 months said:

"...I feel more solidarity. I think that before I was always criticising some aspects of human rights in France, but now when I am in Russia, I can see that this is not true. Because the way that they see human rights here in Russia is very different. So yes, now I feel more proud of my country. They are very proud of their country, they are very proud of their army, of everything, and sometimes in a way that is ridiculous." They are proud that they are so powerful, to have the biggest country in the world, and they 
always think that when something happens like in Ukraine, it is never their fault. Because they are powerful and sometimes very annoying..."

The three responses as cited above can be contrasted with responses from answers by respondents who have lived in Russia for longer periods of time. Respondents seem to become more aware of other points of view the longer they live in Russia. The prevailing Russian point of view at the present time can be said to be anti-western, and this attitude is perceptible but not predominant in the following respondent's answers. A French charity worker (3 years in Russia) said:

"... before I would have considered this Crimea thing to be illegal. I realise that I have read a lot of books by Russian authors who were born in Crimea, the number of authors who were trained in Crimea and Ukraine. Ukraine is the origin of Russia, it's the cradle. I haven't spoken so much with Ukrainians, except last week I met the wife of the ambassador of the Ukraine, and she was crying about the state of her country, saying that four years ago it was so beautiful because you could be with Russia, there was no war, we didn't talk politics, she just said that the war is horrible, and I agree... I am learning to listen."

"Has your attitude towards your own country's foreign policy changed at all?"

"Yes I feel that we are too self-righteous in many things. It's totally obnoxious. And then we point the finger to Russia, of course they are bad. And this is mixed up with the Russian paranoia. I think it is not arrogance, it is paranoia. They are being constantly criticised, even from the time of the Tsars, then the communists, Russia has always been a bad country, inferior to us."

This respondent, who like all the other expatriates interviewed, came to Rus- sia without any significant prior knowledge of the country, but has been reading about Russia and Russian culture since, "...by Russian authors who were born in Crimea," now expresses that her attitude to Russia has, in part, changed: "Before I would have considered this Crimea thing to be illegal." However now, she is: "...learning to listen." The fact that she does not differentiate between Crimea and Russia indicates that she has accepted the Russian view that Crimea is part of Russia.

All expatriates who have lived in Russia for an extended time reported becoming aware of, and taking seriously other points of view. A British CEO, resident in Russia for 3 years said:

“...I can look at a lot of statements about Russian foreign policy, and feel myself surprised and alarmed, and very concerned. So much for the East West balance if I can put it like that... On the other hand, I've lost trust in western foreign policy as well. Because of people like Edward Snowden, because of WikiLeaks, and so on and so on and so on. When I look at the way that foreign policy has evolved, starting with George W. Bush and beyond, I really can't say it's black and white, I can see what I don't like and don't admire about Russian foreign policy but I must say that I am not that much more enamoured by western foreign policy either."

The respondent would presumably have been aware of WikiLeaks and other sources before coming to Russia, but living in Russia seems to have encouraged him and other respondents, to take alternative sources of information and views more seriously. This same respondent's views on his own country's politics show an equal amount of new found plurality in political thinking:

"If I think of Britain's foreign policy, I think that Russia's aggression on its borders 
has not been matched by British aggression in the world. I think that none of us are proud of what happened in Iraq."

Both the French charity worker, resident in Russia for 3 years and the British $\mathrm{CEO}$, resident in Russia for 3 years expressed that their awareness of Russia as being an object of criticism and possibly of Russophobia has increased along with the duration of their stay in Russia $[6 ; 25]$. "And then we point the finger to Russia, of course they are bad." A British headmaster, resident in Russia for 5 years emphasised this point and made direct references to the western media:

"I suppose in the past I could have been very convinced and brainwashed that there is the East and the West, and there are the baddies and the goodies, but the longer I have been here, the way that the western press portrays Russia, you can see it as being very manipulative I suppose as all press is manipulative, but I am not being naive. ...So being here, it does give me a different insight. Also through my job. It is very difficult to recruit staff to come to Moscow because they have a very very biased, negative perception of what life in Moscow must be like. ...Maybe it is just a naïve approach, there's a lot of things happening which obviously I am not aware of, but it doesn't sort of cloud my view."

This respondent said that he has now realised that he could have been "brainwashed" by western media's portrayals of Russia. Interestingly, he expresses that he sees this more clearly the longer he is in Russia: "but the longer I have been here, the way that the western press portrays Russia, you can see it as being very manipulative." The link with time, repeated throughout the interviews can be said to corroborate the idea that increased awareness of Russia's point of view, and of other perspec- tives of respondents' own societies does alter in parallel with time spent in Russia and being immersed in Russian culture.

Like many of the more long-term expatriates interviewed, this respondent expresses his experiences through professional experiences. Some expatriates who work for foreign companies in Russia seem to experience tensions between their bosses' expectations (bosses who are not based in Russia), and the reality 'on the ground' in Russia. Such tensions may serve to accelerate coming to a deeper understanding of both western, and Russian points of view, as the expatriate is often in the middle of negotiations between two sides who cannot understand each other's points of view.

It is interesting that this respondent sees that the way the western press sees Russia is: “... very manipulative.” What he perceives to be the bad quality of the western press seems to push him to adopting a more questioning position as regarding the correctness of western attitudes towards Russia. Interestingly, whilst this respondent is aware that his approach may be naive, this "...doesn't sort of cloud my view." Some confusion may be evident in this statement.

The impact of Russian culture on expatriates who have lived in Russia for longer periods of time appears to be strong. A British journalist resident in Russia for 7.5 years who works as a correspondent for a mainstream British news agency, and thus is not paid to disseminate the Russian point of view of the world expressed:

"...So if I was being very broad, perhaps a little bit lazy in my thinking, I would say the more I knew the less I liked. But it obviously isn't as simple as that. There are constructive things in Russia's foreign policy as well. I suppose it may have developed along a con- 
sistent course, but I didn't know an awful lot, at least I realise how little I knew then..."

This respondent appears to be referring to facts, rather than emotions. It is interesting that for him, on a logical level, he recognises that he "...didn't know an awful lot," perhaps conceding that there is another aspect of Russia which he was not familiar with.

A Canadian Banker, resident in Russia for 18 years, also indicated a preparedness to listen to both points of view.

"... So I try and understand both sides of the situation, not just in foreign policy. I can understand the motivation of the other side even if I don't agree with it. I am the one who is accused of being an apologist for Putin because I do try and understand Russian foreign policy, but I don't agree with American foreign policy either because it seems to be all about meddling in other countries' affairs. ...I have found it more difficult to accept the kowtowing to American security interests that other previous conservative governments have made. When the liberals came back in last year, they are trying to be a little more independent."

He added:

"Recently I have become amazed how little people are aware of the outer world in the United States, and how few people are involved and have an opinion about international affairs. And yet here is this country which is having the biggest influence on international affairs, yet it is a relatively small amount of people involved, with relatively little constraint..."

This respondent clearly states his ability to see both sides of the fence, even at the risk of being called an "...apologist for Putin....", which appears to be something that he has now become blaseì about. He recognises that becoming aware of “...both sides of the situation..." makes it more difficult to completely accept either side's point of view: "...I have found it more difficult to accept the kowtowing to American security interests...," and indicates that this is a direct result of becoming more aware of Russian culture. He now finds it surprising how little Americans know about the “...outer world...". This respondent's views seem to have cardinally altered by long term exposure to Russian culture, yet at the same time he is not insisting that any one side is right. A British Agriculturist and Hotelier, resident in Russia for 25 years said:

"My stance towards Russian foreign policy has been influenced by a greater understanding of the fact of just how much the western general public are unaware of Russian culture, history etc. I would say even ignorant."

This respondent also makes it clear that for him, Russian foreign policy is misunderstood by the West because westerners, are "...unaware of Russian culture, history etc. I would say even ignorant." The "... even ignorant" could indicate that Russian culture, in his opinion, is not something that one should be ignorant of if you happen to be dealing with Russia. This view is corroborated in his reply concerning his views about British culture:

"If you are becoming more involved with Russian culture, do you feel yourself becoming alienated from your own culture in any way?"

"No, just more aware that mine was not the only centre of world culture."

The important point for this paper is the use of the past tense: “...was..." indicating the temporal aspect of how culture can be seen to transform expatriates view of culture, politics and identity. As with the British journalist, he is saying that 
his life in Russia has enabled him to see the importance of respecting and understanding other cultures. The ability to see situations from two points of view appears to bring long term expatriates the perceived understanding that viewing the world only from one vantage point entails prejudice. It is clear, however, that knowledge of more than one point of view places long term expatriates in a different position from those expatriates who have arrived in Russia comparatively recently, in that 'long-timers' seem to reject adopting a for or against, black and white approach to politics which may be present in their home country's political stance, as for that matter it is in Russia's.

To sum up this section, it is clear that all respondents indicate that Russian culture has impacted their political views, but not in a simple, dualistic manner. When the time factor is included it becomes clear that Russian culture impacts expatriates in a transformational way. Those expatriates who have arrived comparatively recently seemed to demonstrate an inclination to view Russian culture through their own cultural and political understandings and reject what they have found. One possible explanation could be that when confronted by a tidal wave of culture and political thinking which is different and possibly more unified than their own culture and political thinking; they try to rationalise their experiences in terms of their own national identity. It is possible that this is a defensive mechanism. Expatriates who have resided in Russia for longer periods of time seemed more inclined to accept that the Russian experience is not a threat to their existing identity, although this may result in contradictions and what could be interpreted as cultural and political disorientation; as two identities seem to coexist inside one being. The unique position that expatriates in Russia find themselves in; that is working with and for people who may not live in Russia, and at the same time managing staff in Russia; thus having to understand both cultures, perhaps encourages them to understand both sides of the fence, for their survival.

Those expatriates who have resided in Russia for decades seem to be have resolved possible internal conflict and are apparently able to see "...both sides of the situation..." clearly. For them there is no confusion, the picture is clear. This does not mean, however that the 'long-timers' are firmly anti-western, and 'pro-Russian, meaning that the Russian 'side' has won, it means that they 'can live with' the existence of more than one identity, and have gained from the ability to acknowledge the reality of two different points of view. Expatriates interviewed did not talk about the impact of globalisation on Russia, as was suggested might be an important consideration earlier in this paper. Expatriates did, however mention the awareness of bias in the western media, “... in the past I could have been very convinced and brainwashed that there is the East and the West..." (British headmaster, resident in Russia for 5 years), which supports the view that Russophobia exists, and has historic roots (see literature review) is worthy of consideration. The singular and most important point for the purposes of this paper is that culture has a clear impact on expatriates' political views, as it can be said that seeing faults and advantages of one's own and other countries' political systems is not common practice amongst populations who reside for most of their lives culturally and geographically within the boundaries of territory encompassing one national identity. 
The findings in this section support Mamdani's point about 'Culture Talk' (see introduction) which 'assumes that every culture has a tangible essence that defines it, and then explains politics as a consequence of that essence' [26]. Seeing '.. both sides of the situation...' supports Cuccioletta's view that 'we are of all the cultures. Each person is a mosaic' [18]. The view that 'tolerating and respecting' is a way to 'prevent or at least mitigate some of the most pressing security concerns of our day' as offered by Transculturism [2, p. 13] is given support by the above findings.

\subsection{The Role of Culture as a Trans- formational Force}

It has been seen in the above interviews that residence in Russia affects expatriates' political views over time. This section delves deeper into the effect of Russian culture itself in a process which can be identified as being transformational; that is, having an effect over time.

The case for culture as being a transformational force was made unequivocally by a British writer (10 years in Russia) who stated:

"I want to say that culture informs politics to a massively greater extent than people think. The Russian understanding of life is different from the British understanding. You are really dealing with a different culture."

"Are Russian politics formed from the crucible of Russian culture?

"Yes, absolutely, I would totally agree with that." The point that this respondent makes, is that politics is informed by culture. "...to a massively greater extent than people think." However, there is another side to this argument which does not deflate the value of his statement. That is, the view that if Russian politics are formed from the crucible of Russian culture, then Russian politicians can use Russian culture to promote their political agendas, if those agendas engage within the general parameters of Russian culture. In terms of securitisation theory (as mentioned in chapters 1 and 2), this means that culture could be 'securitised' for political ends as long as the political strategy is grounded in Russian culture. The same could be argued for political activity anywhere in the world.

In response to the question "How has your exposure to Russian culture influenced your view of Russian politics?," a British CEO resident in Russia for 3 years said:

"I would say that my exposure to Russian culture has helped me to understand why Russian foreign policy tends to emerge the way that it does. What I mean by that is that I think I'm far more aware of Russian history and the difficulties that Russians have overcome during their history. And the wariness they have to potential threats to their borders. I've never felt as a Brit that our borders are threatened that much.... Whether the way they [politicians] behave in the specific way of foreign policy is a reflection of how the masses feel they should behave I am less clear. Because I do sense there is a disconnect between the way that I describe Russia and the way that diplomacy and foreign policy seems to work."

The respondent also clearly expresses that he sees a link between Russian culture and politics, however he feels that there may be a disconnect between the way "...how the masses feel", and Russian politics. He may be indicating the "masses" are somehow connected to Russian culture, and the way that Russian politicians behave. This view could be seen to be incongruent with that offered by the 
previous respondent who stated that Russian politics are created in the crucible of Russian culture.

The role of Russian culture in Russian history is clearly expressed by the French Charity worker, resident in Russia for 3 years:

"Yes, they have a thing that is totally unknown to me, and that is, a love for this life. Russia is something that is so much in their guts, English are very patriotic, but it's for the Queen, it's not for the land, it is more superficial. But for them, Russia, Russ, Kiev, which explains the Ukraine thing, the roots of Russia are so, so vivid, in their judgements, minds, and of course you can always say that there is a lot of brain washing, and there have been television programmes about it that, radio programmes about that.

Living in Russia has made this respondent aware the depth of Russians' love for the land. Her appraisal of Russians' attitude to their own country has tinges of slavophilism. This respondent links Russian culture with history, although no reference is given to which version of Russian history [27, p. 104] we are talking about, but it is presumably the version of Russian history which is currently on a surface level at the present time in Russia. Be this as it may, the point that Russia as a country cannot alienate itself from its past is clearly made.

The Canadian Banker (in Russia for 18 years) sees culture as being something fluid, yet at the same time, long lasting:

"Culture doesn't change as a unifying thing. Culture changes as individuals change, as each individual sees something different in it. I do see some changes in Russian culture, some significant changes, mostly among young people. Not all Russian people, because a lot of young people are still working for what I call Soviet institutions. Families don't change just because there's a revolution, my wife's parents are still very Soviet, they have a stronger sense of time and family, individuals change, but culture itself doesn't change. Although we have had 25 years of 'capitalism' the number of people who work in a relatively normal capitalist company is still very small. The number who have been able to work in that environment and succeed is very small. So the peoples setting the environment for new people coming into the workforce, are still highly based in a Soviet mentality. In all respects, in terms of communication, space, time. If we are seeing a change in culture and I believe we are, you may be able to see a significant difference in 30 years. Maybe in another thirty years after that, it may move again in some direction, and not necessarily in a direction which is closer to America. It may move closer to Germany, or China."

This respondent sees Russian culture as being a steady reference point around which such phenomena as 'capitalism' and 'Soviet institutions' appear and disappear. Durkheim's point about society having a 'reality of its own', not to be reduced to an individual level, is relevant here (Durkheim quoted in [41, p. 18]). Russian culture is, according to this respondent and to all respondents who have lived in Russia for over 10 years, awarded the status of timelessness.

This statement offers one explanation of why expatriates' attitudes towards Russia is impacted by Russian culture, because they become aware of something more lasting than themselves. Something which they fit into; "Culture doesn't change as a unifying thing. Culture changes as individuals change, as each individual sees something different in it." In this sense, 
Russian culture may be perceived as being what Tönnies's termed: 'Gemeinschaft' (community), (Tönnies, quoted in [41, p. 18]). The respondent's comment: “... but culture itself doesn't change" would indicate more of a community approach to society. Elsewhere in his interview, the respondent talks about understanding both sides: "I can understand the motivation of the other side even if I don't agree with it." The recognition of the 'Gemeinschaft' approach does not nullify the existence of the 'Gesellscaft,' as far as expatriates are concerned.

In the context of discussing Russian culture, it may be interesting to consider what an Australian teacher, resident in Russia for 2 years, views as Russian culture:

"Yesterday I was walking from the Christ the Saviour building to Gorky [Park] and I noticed that there are tons of mini art galleries as you are walking across, in the parks they have set up mini photography exhibitions, I stopped and hung around them for an hour and I just can't wait to see those kind of things. So I think that there's ways to immerse in that kind of thing without having to go to the Pushkin Museum or the Tret'yakov Gallery. ...I think celebrations are pretty important as well. Maslenitsa and the whole holiday around it is pretty important."

For this respondent, Russian culture is not high art; neither is it for any of the respondents, as all respondents paid tribute to the theatre, the opera and ballet, however nobody referred to these aspects of culture as constituting the whole of Russian culture. For this respondent and for other respondents who have recently arrived, Russian culture appears to be more of a mind-set, a collection of 'concepts' reflecting everyday life. This can include considering "Maslenitsa and the whole holiday around it..." as being "...pretty important." Maslenitsa is commonly known as being a Christian festival with deep roots in paganism, and at first sight cannot be classified as being of the same sort of culture as street art exhibitions, and yet it is still appreciated by the expatriate who has lived in Russia for 2 years to be part of the overall package of Russian culture, on a par with street exhibitions. This could be because all of it; the street exhibitions and the religious festival are so different from her previous cultural experiences that they become enmeshed in a general term called culture.

Evidence for the latter point of view is provided by respondents who have lived in Russia for a very long time appear to be able to assimilate all aspects of Russian culture into one universal all-embracing experience. The British Agriculturist and Hotelier, resident in Russia for 25 years said that Russian culture for him is:

"A complete mix of history, music, art, drama, village life, the complete cocktail, without which it is difficult to touch, or understand the Russian soul and spirit."

The idea that Russian culture is a form of Bakhtian carnival which embraces the individual and encompasses all aspects of culture, and only through passing though this can one understand the "Russian soul and spirit" can be interpreted in many ways. If we consider culture to be somehow reified to become a multi-faceted living entity which includes "Maslenitsa" as well as street "mini-exhibitions," culture becomes all and nothing - it can be delimited from known cultural institutions, from ideas such as "capitalism" and "Soviet institutions" but on the other hand includes "...history, music, art..." as well as "drama, village life," into a "complete 
cocktail...” In this context, it is perhaps no wonder that foreigners who have recently arrived, when immersed into Russian culture retreat to the safety of their own cultural worlds.

From the data provided, the longer the expatriate lives in Russia, the stronger his or her experience, perhaps on a sub-conscious level becomes that Russian culture is something timeless and all-embracing. Russian culture appears to have a stronger 'Gemeinschaft' quality, than western cultures, which may mean that by living inside Russian culture, inside the 'truth' ('Pravda') of Russian culture, which tends to be exclusive by nature, expatriates tends to adapt, almost by a process of osmosis, to one Russian collective cultural spirit. This is not to say that there are not large numbers of Russians who do not fit into the commonly accepted 'truth', however the long-term expatriates who participated in this research clearly do.

What can be said with a reasonable degree of certainty, as can be seen from citations in this section, is that expatriates become more open-minded and thus able to understand both western and Russian points of view more deeply. This led the researcher to consider that long-term expatriates' political views are genuinely broader than they were before they came to Russia, at least in the context of understanding Russia. Expatriates become aware of another variant of the 'truth.' In this context, culture can be seen to include aspects of geography, as can be seen by the fact that these interviews were all carried out in Russia. A possible conclusion of this section is that in the long-term expatriates in Russia, over time, see the 'we' in more than one culture. This does not necessarily mean they agree totally with one or the other point of view, but it does indicate that they foster tolerance and understanding for the culture of their host country. Such an understanding lies at the heart of transculturism.

It is possible to suggest, based on the discussions in this section, that long-term expatriates view Russian culture more of a long-term phenomenon, which embraces the individual "A complete mix of history, music, art, drama, village life, the complete cocktail," said the British agriculturist and hotelier resident in Russia for 25 years. This would tend to support a view that Russian culture contains essentialist elements. The Canadian banker, resident in Russian for 18 years said: "....If we are seeing a change in culture and I believe we are, you may be able to see a significant difference in 30 years."

This does not mean that all cultures contain an essentialist element, as this research is focussed on Russian culture only. Some cultures may be more essentialist than others. However, the implications of this for global security are plain to see. McSweeney's concern that the concept of societal security risks legitimising the notions of 'us' and 'them' (see introduction) is perhaps not valid in the light of this research. One could argue the opposite, that becoming aware of "...both sides of the situation..." heightens the awareness that in fact 'we are of all the cultures' (quoted in [18]).

\subsection{Other Relevant Results}

There are several other factors of importance to this paper which have come to light from the data that was gathered. Firstly, in the context of credibility of data, it was necessary to establish whether or not expatriates' links with home are under threat in any way. If this is so, this could indicate that they are open to being influenced by what is known as Russian prop- 
aganda, and this could even be seen as a security threat (to them). All respondents said that they travel home frequently, and most have family 'at home.' One respondent, however, the Canadian banker, resident in Russian for 18 years, said that Russia is his home:

"I live here, this is my home. I do go home regularly... For the kids, once during the summer holidays. I have a son, daughter-in-law, two grandchildren in Toronto and other family in Vancouver, California and Texas."

The British writer, resident in Russia for 10 years said:

"I have a flat there, I go there quite a lot, I have loads of friends there, on the whole, I think I spend probably 6 weeks a year in the UK, so I'm part of society there too if you like. There is also Skype, I'm in contact with people in the UK on Skype a lot."

No respondents consider themselves to have been cut off from their homelands. Broadband seems to be playing an increasingly important role in communications, which give rise to the possibility that transnational identities have become a reality in the life of expatriates in Russia. The personal wealth of these expatriates who are able to afford to support an international lifestyle is also evident.

Expatriates are often accused of having succumbed to what is called 'Russian propaganda' if they hold views which vary from those held by the mainstream press in their native countries, which at the present time appears to be different from the views expressed by the Russian electronic media. When asked whether they have been affected by this, the responses were negative. The following responses are representative of views held by all respondents: The British writer, resident in Russia for 10 years said:
"No. Well except in the opposite way. Sometimes if I hear Putin saying something I will assume the opposite. Propaganda makes me more sceptical about what they say."

An Australian teacher, resident in Russia for 2 years said:

"Not really, but do you know? When Victory Day happened, I actually felt really proud to be in Russia. I'm not even Russian, but I felt YES, Many times during these kinds of holidays I feel proud to be in Russia! When I go back home and showed my sister photos she says it's so funny how nationalistic they are. Maybe I have been brainwashed!"

Both respondents are ridiculing the suggestion that they have been brainwashed, although the Australian teacher may be indicating through humour (the printed word does not reflect the intonation of the speaker, which in this case was one of jest) that she feels there may be something she can respect in the Victory Day celebrations.

Language has long been considered be an important part of any culture: 'Empirically, it might be that language and culture are the main objects to which people make reference when they argue who "we" are: why "we" belong together [41, p. 40]. Perhaps surprisingly, data revealed that none of the expatriates interviewed said that they spoke Russian fluently. The British journalist, resident in Russia for 7.5 years, for example, said that he does not have time for Russian classes:

"Yes, I have done one on one classes for a number of years, I'm not currently doing those, it sort of goes in waves, I spend so much of the time working that I don't have the time, but I have done them extensively in the past and I have tried to expose myself through work and through obviously my family life, friends, who speak Russian." 
The British writer, resident in Russia for 10 years who advocated that "...culture informs politics to a massively greater extent than people think," said that he is learning Russian: "...just by osmosis."

The reason why he doesn't study Russian formally is that:

"Too expensive. I can read what I need to read reasonably well, not that well, and I can speak and understand reasonably well, not as well as I can read, I would like to know more Russian but I can't be bothered studying it..."

The Canadian banker, resident in Russian for 18 years said: time."

"We speak Russian at home most of the

It is perhaps necessary to note that all of the above respondents, who have lived in Russia for long periods of time are married to Russians, and "...speak Russian at home," something that may not be as easy as it may sound, even after having studied Russian formally to degree level (which none of the respondents did). In the opinion of the researcher, understanding intellectually the grammar and structure of Russian is only one aspect; understanding how to correctly use words contextually implies cultural knowledge, which only comes from cultural immersion. This data could indicate that immersion in Russian culture may not be something that can be measured in terms of how well one speaks or does not speak the language.

One respondent, the French charity worker, resident in Russia for 3 years, did make some interesting statements about Russian:

"I really consider that languages reflect totally the mentality of the people. My Russian teacher one day said, "Xxx, you have to understand, that in Russian, the subject is always passive." To me it was like, wow.
Does she realise what she has just said? The submissiveness to any power, no revolt, inflation, low wages and everything, submissively. I need to find another word, not submissiveness, in French we have a lot of words to describe this, fatalistic - they are fatalistic. It's like - who cares? Something like - I'm here for a short time, that's amazing. There is so much in the language. The women marries behind the man, and the woman walks behind the man, when you say 'замужем' (zamuzhem) it reflects a very traditional society which I don't agree with, I don't feel comfortable with everything, but some part of it is that ancient ancient wisdom, which is in the language, which is also in the mind set."

This respondent, who is an academic makes a connection between the Russian language and Russian culture. She has become aware that Russian culture, through language is bound to time, and in this sense, supports the view that Russian language affects Russian culture in an essentialist manner.

In this section, evidence has been provided to support the credibility of this paper by establishing that expatriates are not cut off from their own cultures and politics, and have not succumbed to 'Russian propaganda.' The ridiculing of the effect of 'Russian Propaganda' by all expatriates would seem to indicate not that the propaganda itself is ineffective for the Russian population, although that may be the case for the educated in Russia's major cities, but that being aware of two cultures, gives expatriates the ability to view both countries' medias as having the potential to produce propaganda, as was pointed out in section 4.1. by the British headmaster, resident in Russia for 5 years:

"...I could have been very convinced and brainwashed that there is the East and the 
West, and there are the baddies and the goodies, but the longer I have been here, the way that the western press portrays Russia, you can see it as being very manipulative..."

Data shows that there is no clear link between knowing Russian formally and being immersed in Russian culture. This could point out that language without context does not equal cultural knowledge. This could have implications on the training of foreign policy experts, in that language training without cultural immersion does not bring an understanding of Russian culture.

\section{Conclusion}

The analysis of data gathered in the course of research as presented in the previous chapter shows that long-term residence in Russia and immersion within Russian culture has an impact on western expatriates. Respondents indicated that Russian culture appears to have a transformation effect, which alters expatriates' political outlook by making them aware of different cultural perspectives, depending upon primarily the amount of time that they have been exposed to it. Such a result points to the view that politics does not operate in isolation to culture. The implication for global security is that to understand a country's foreign country's politics, it is advantageous to understand its culture.

Data showed that choosing Russia as a case study was useful, because the contrast between Russian and Western cultures is tangible, and yet Russian culture, being European is accessible to western expatriates. Furthermore, the East-West political environments when research was carried out, were sufficiently different to create situations where respondents' political orientation has been seen, by data gathered, to be challenged. This is in contrast to the situation of American expatriates in Europe [22], where cultural and political differences are not as great, and where it would not be so easy for expatriates to identify culture as being the "crucible" in which politics are framed.

Key empirical findings which highlighted how in-depth engagement with a country and a culture enables greater understanding of a country and its politics included evidence to suggest that longterm expatriates in Russia are not only able to see "...both sides of the situation...", but function within a foreign culture adequately using their newly acquired perspectives, whilst still retaining a place in their own societies. If anything their many successes in Russia can be seen to be because they are able to see the 'we' in the 'other'. They become examples of what Guy Scarpetta described as 'cultural impurity' (Scarpetta quoted in $[18$, p. 3]). This evidence challenges certain well-formed opinions about culture and politics. The view of Huntington that cultures have a structural tendency to clash is put into question [21, p. 22] by data in this paper.

This paper, however, suggests that 'societal security's' actual contribution to the debate on global security can be seen to be problematic. The Copenhagen school's theories, in general terms, appear to have been created primarily in the context of solving and avoiding conflicts within the EU, which is or was moving in the direction of integration, enjoys a collective security arrangement and a debatable sense of pan-European culture. Arguments for or against the inclusion of culture at the high table of global security based on theories which were developed within an alliance of integrating countries is one thing. Arguments for and against the inclusion of culture when formulating secu- 
rity strategies with countries and blocks of countries with different cultural and thus political principles is another. "I want to say that culture informs politics to a massively greater extent than people think.," said the British writer, resident in Russian for 10 years. Assessing culture to be more important than other sectors of security, however, is not the goal of this paper, the goal of this paper is to give evidence to the argument that culture in global security is at least as important as other sectors.

Transculturism, which seems to set its goals as the establishment of synergies between 'cultural groups and civilizational forms' [2, p. 13] perhaps points towards a way forward in global security as it includes 'transcultural security' as a sector within security. However, transculturism, as discussed in the literature review, remains untested and would demand the willingness of governments, and not only those which operate within an alliance of countries, to allow transcultural security. The willingness of governments to voluntarily do this is an unknown factor. A considerable amount of time may elapse before the principles behind transculturism, or the theory(ies) that is/are developed from it, are applied in practice, if ever, and this may never happen between countries that are opposed to each other. It would appear from research undertaken in this paper that culture is used as a weapon in the international arena. Progress in this area; in the direction of resolution and prevention of conflict could involve more inter-cultural communication, and destruction of cultural myths, which may have been intentionally created or intentionally sustained. A fresh, non-judgemental approach to people from other cultures is needed in order to see the 'we' in the 'other.'
Be this as it may, the suggestion that 'plurality of cultures can have a net effect on global security that is greater than would be the case if representatives of individual cultures acted individually' [2, p. 13] can be seen to be important as it could create the premise for the creation of a new way of thinking about global security that explores the importance of culture. In the face of transnational threats, countries have to work together.

Be this as it may, by way of discussing the effect of culture on global security, this paper has raised the topic that immersion into Russian culture creates insights into Russia that may be useful for governments now. Governments may consider that language without context, as shown by data in this paper means that individuals may not fully comprehend what is happening in Russia. Lack of understanding can lead to incorrect decisions. The lack of Russian experts in countries' international departments (named differently for each country) may have serious negative implications (UK struggles with language of Russian diplomacy [17]) in international relations, because of lack of ability to see "...both sides of the situation..," an ability that lies at the heart of diplomacy.

This paper can be criticised for only studying the impact of culture on political orientation in one country; Russia. To study further the relationship between culture and politics, and thus to firm up ideas offered in this paper, it would be interesting to study the impact of western culture on Russian expatriates in Europe, for example. Direct comparisons with data offered in this paper may be difficult however, as the motivations for Russians travelling to Europe to work could be different. Ideas suggested in this paper could perhaps benefit from further research into 
how lasting the changes in political orientation of western expatriates are, by interviewing expatriates who have returned to the West, again, over different periods of time. The accessibility of cultures could be further studied by interviewing western expatriates in other parts of the world, such as in China.

Such ideas could further advance the cause of understanding the relationship between politics and culture, however this paper has, perhaps, pointed out that such an understanding is not enough. Current global security theory does not pay enough attention to culture. The creation of a new theory, or development of existing theories which offers a pragmatic way forward in terms of global security which places due respect on culture would seem, to the author of this paper, to be a very worthwhile and necessary endeavour.

\section{Appendix. Interview Topic Guides}

Theme 1: Longevity of stay in Russia

- How long have you lived in Russia? Do you live here all the time?

- Do you travel home regularly?

- Do you have family at home?

Theme 2: Contact with Russians

- In what ways do you find yourself socialising with Russians?

- Do you socialise with foreigners as well?

- Do you think that communicating with Russians has affected the way in which you communicate with foreigners?

- Is your partner Russian?

- May I ask how long have you been together?

- What are your feelings about Russia's attitudes to gays and lesbians?
Theme 3: Russian language skills

- Did you learn Russian before coming here?

- Are you learning the language now, formally or informally?

- Is it too much trouble and too time consuming to learn Russian? Any other reason?

\section{Theme 4: Culture}

- Are you interested in Russian culture?

- What is culture, in your opinion?

- Do you read books by Russian authors?

- Are you interested in Russian Art/ Films/Theatre?

- Do you think that Russian culture has helped you to see your own culture in a different way?

- Has been aware of, and learning about Russian culture made it easier for you to understand how Russians see the world?

- Could you try and explain in what ways?

- If you are becoming more involved with Russian culture, do you feel yourself becoming alienated from your own culture in any way?

\section{Politics}

- Do you feel your attitude towards Russia's foreign policy has changed in any way over the course of your stay in Russia in any way?

- If it has changed, do you think that this is somehow connected with your exposure to Russian culture?

- Has your attitude towards your own country's foreign policy changed at all?

Статья поступила в редакцию 12.02.2019 


\section{REFERENCES}

1. Abashin S. Central Asian migration. In: Russian Politics and Law, 2013, vol. 51, iss. 3, pp. 6-20.

2. Al-Rodhan N. R. F. The Five dimensions of global security: Proposal for a multi-sum security principle. Germany Lit Verlag, 2007. $160 \mathrm{~s}$.

3. Appadurai A. Modernity at large: Cultural dimensions of globalization. Minneapolis, University of Minnesota Press, 1996. 229 p.

4. Austin J. L., Sbisaİ M. How to do things with words, ed. J. O. Urmson, M. Sbisa. $2^{\text {nd }}$ ed. Cambridge, Massachusetts, Harvard University Press, 1975. 184 p.

5. Baumann G. The multicultural riddle: Rethinking national, ethnic, and religious identities. New York, Routledge Publ., 1999. 188 p.

6. Bonnett A. The idea of the west: Culture, politics and history. United States, Palgrave Macmillan, 2004. $216 \mathrm{p}$.

7. Bourdieu P. Outline of a theory of practice. Cambridge, Cambridge University Press Publ., 1977. 248 p.

8. Brewer P., Venaik S. Individualism-Collectivism in Hofstede and GLOBE. In: Journal of International Business Studies, 2011, vol. 42, no. 3, pp. 436-445.

9. Brown J. D. J. A stereotype, wrapped in a Clicheì, inside a caricature: Russian foreign policy and Orientalism. In: Politics, 2010, vol. 30, no. 3, pp. 149-159.

10. Brubaker R., Cooper F. Beyond “Identity". In: Theory and Society, 2000, vol. 29, no. 1, pp. 1-47.

11. Bryman A. Social research methods. $4^{\text {th }}$ ed. New York, Oxford University Press, 2008. 809 p.

12. Buzan B., Waever O., Wilde J. de. Security: A new framework for analysis. Boulder, CO, Rienner Publishers, 1998. 239 p.

13. Caldwell M. L. Domesticating the French fry: McDonald's and consumerism in Moscow. In: Journal of Consumer Culture, 2004, no. 4 (1), pp. 5-26.

14. Chapter V of The United Nations: The Security Council. In: United Nations. Available at: http://www.un.org/en/sections/un-charter/chapter-v (accessed: 22.06.2016).

15. Cole P. M., Tamang B. L., Shrestha S. Cultural variations in the socialization of young children's anger and shame. In: Child Development, 2006, vol. 77, no. 5, pp. 1237-1251.

16. Collins A., ed. Contemporary security studies. New York, Oxford University Press, 2006. $480 \mathrm{p}$.

17. Coomarasamy J. UK struggles with language of Russian diplomacy. In: $B B C$. Available at: http://www.bbc.co.uk/news/world-europe-31856880 (accessed: 28.08.2016).

18. Cuccioletta D. Multiculturalism or transculturalism: Towards a cosmopolitan citizenship. In: London Journal of Canadian Studies, 2002, vol. 17, pp. 1-17.

19. Gorodnichenko Yu., Roland G. Are there cultural obstacles to democratisation? In: VOX, CEPR Policy Portal. Available at: http://voxeu.org/article/role-culture-democratisation (accessed: 27.08.2016).

20. Hall E. T. T. The silent language. New York, Anchor, 1973. 217 p.

21. Huntington S. P. The clash of civilizations: And the Remaking of world order. New York, Simon \& Schuster, 1997. 367 p.

22. Klekowskivon Koppenfels A. Migrants or expatriates? Americans in Europe. United Kingdom, Palgrave Macmillan, 2014. 330 p.

23. Krause K., Williams M. C., eds. Critical security studies: Concepts and cases. Minneapolis, University of Minnesota Press, 1997. 404 p.

24. Laruelle M. Central Asian Labor Migrants in Russia: The "Diasporization" of the Central Asian States? In: China and Eurasia Forum Quarterly, 2007, vol. 5, no. 3, pp. 101-119.

25. Lieven A. Against Russophobia. In: World Policy Journal, 2000, vol. 17, no. 4, pp. 25-32. 
26. Mamdani M. Good Muslim, bad Muslim: America, the cold war, and the roots of terror. New York, Three Leaves Press; Doubleday, 2005. 320 p.

27. Marsh R. J. Literature, history and identity in post-soviet Russia, 1991-2006. New York, Peter Lang AG, 2007. 594 p.

28. McSweeney B. Security, identity and interests: A sociology of international relations. Cambridge, Cambridge University Press, 1999. 256 p.

29. Moscow expat Survey 2015. In: Moscow expat Life. Available at: http://moscowexpatlife. ru/2015/09/moscow-expat-survey-2015 (accessed: 05.06.2016).

30. Ritchie, J., Lewis J., eds. Qualitative research practice: A guide for social science students and researchers. London, Sage Publications, 2003. 352 p.

31. Roe P. The Societal Dimension of Global Security. In: Global Security and International Political Economy-VI, 2010, vol. 1, pp. 113-132.

32. Samovar L. A., Porter R. E., eds. Intercultural communication: A reader. Belmont, California, Wadsworth Publ., 1972. 437 p.

33. Smith A. D. National identity. New York, Penguin Books, 1991. 230 p.

34. Spengler O. The decline of The West: in 2 vols. (Der Untergang des Abendlandes). London: Allen \& Unwin, 1918.

35. Thucydides. The history of the Peloponnesian war. Boston, IndyPublish.com, 1999. 441 p.

36. Ullman R. H. Redefining security. In: International Security, 1983, vol. 8, no. 1, pp. 129-153.

37. Urban M. The politics of identity in Russia's Postcommunist transition: The nation against itself. In: Slavic Review, 1994, vol. 53, no. 3, pp. 733-765.

38. Vaughan-Williams N., Peoples C. Critical security studies: An introduction. New York, Taylor \& Francis, 2010. 192 p.

39. Vertovec S. The cultural politics of nation and migration. In: Annual Review of Anthropology, 2011, vol. 40 (1), pp. 241-256.

40. Vuori J. A. Illocutionary logic and strands of securitization: Applying the theory of securitization to the study of non-democratic political orders. In: European Journal of International Relations, 2008, vol. 14(1), pp. 65-99.

41. Wæver O., Buzan B., Kelstrup M. Identity, migration and the new security agenda in Europe. London, Pinter, 1993. 231 p.

42. Who are expats? In: Moscow Expat Life. Available at: http://moscowexpatlife.ru/2014/09/ who-are-expats (accessed: 05.06.2016).

43. Wilkinson C. The Copenhagen school on tour in Kyrgyzstan: Is securitization theory useable outside Europe? In: Security Dialogue, 2007, vol. 38, no. 1, pp. 5-25.

\section{ИНФОРМАЦИЯ ОБ АВТОРЕ}

Харрисон Джон Джордж - старший преподаватель кафедры английской филологии Московского государственного областного университета;

e-mail: harrisonj@outlook.com

\section{INFORMATION ABOUT THE AUTHOR}

John G. Harrison - senior lecturer at the Department of English Philology, Moscow Region State University;

e-mail: harrisonj@outlook.com 


\section{ПРАВИЛЬНАЯССЫЛКАНАСТАТЬЮ}

Харрисон Дж. Дж. Влияние русской культуры на политическую ориентацию эмигрантов из западных стран в России // Вестник Московского государственного областного университета. Серия: Лингвистика. 2019. № 3. С. 113-140.

DOI: $10.18384 / 2310-712 \mathrm{X}-2019-3-113-140$

\section{FOR CITATION}

Harrison J. G. The impact of Russian culture on the politicalorientation of western expatriates in Russia. In: Bulletin of Moscow Region State University. Series: Linguistics, 2019, no. 3, pp. $113-$ 140.

DOI: $10.18384 / 2310-712 \mathrm{X}-2019-3-113-140$ 